\title{
Enhancing Permanence for Vocabulary Learning on 2nd Grade Students in Turkey Through Music ${ }^{1}$
}

Mejora de la Permanencia en el Aprendizaje de Vocabulario en Estudiantes de Segundo Grado en Turquía a Través de la Música

\section{Omer Faruk Tavsanli, Abdullah Kaldirim, and Tayyar Erdem Gedikli2*}

Istanbul Aydin University, Kutahya Dumlupinar University, and Bursa Uludağ University, Turkey

${ }^{1}$ Received: April 8th 2020/ Accepted: April 122021

2 omerfaruktavsanli@gmail.com; abdullahkaldirim@gmail.com; erdemgedikli@gmail.com 


\section{Abstract}

Music plays an important role in students' language development. Because the process of acquiring and developing language skills of the individual and learning to make music work have many similarities. In this quasi-experimental study, teaching the word in L1 with music with the normal intelligence and development level of 2 nd-grade students on the learning of the meaning of the word and ensuring the permanence of the word has been examined. A quasiexperimental design with the experiment and control group was used in the study. In the study words, whose meanings are unlikely to be known by the students, in contexts, and success tests prepared to measure these words' meanings were used as data collection tools. The research was carried out with 43 second-grade students, and the data were analyzed with an ANOVA test. According to the study results, it is concluded that the teaching of vocabulary with music, both the meaning of the word and providing the persistence of learning, was found to be useful. Besides, when the permanence of the words whose meaning is learned is examined, it was revealed that teaching vocabulary with music also supports permanent learning.

Keywords: Music, vocabulary teaching, learning the meaning of the word, permanence, elementary grades, mother tongue

\section{Resumen}

La música juega un papel crucial en el desarrollo del lenguaje de los estudiantes. Porque el proceso de adquirir y desarrollar conocimientos, aptitudes así como habilidades y el proceso de saber como hacer que la música tienen muchas similitudes. En este estudio cuasiexperimental, se examinó el efecto de la enseñanza de la palabra en L1 con música con el nivel normal de inteligencia y desarrollo de los alumnos de $2^{\circ}$ grado sobre el aprendizaje del significado de la palabra y la garantía de la permanencia de la palabra. En las palabras de estudio, cuyos significados apenas son conocidos por los estudiantes, en contextos; y pruebas de éxito preparadas para medir los significados de estas palabras fueron utilizadas como herramienta de recolección de datos. La investigación se realizó con 43 estudiantes de segundo grado y los datos se analizaron con la prueba ANOVA. De acuerdo con los resultados del estudio se concluye que se encontró útil la enseñanza de las palabras con música tanto para el aprendizaje del significado de la palabra como para su sostenibilidad. Además, cuando se examina la permanencia o la constancia de las operaciones se reveló que enseñar vocabulario con música también apoya el aprendizaje permanente.

Palabras Clave: Música, enseñanza de vocabulario, aprendizaje del significado de la palabra, permanencia, grados elementales, lengua materna 


\section{Resumo}

A música cumpre um papel crucial no desenvolvimento da linguagem dos estudantes. $\mathrm{O}$ processo de aquisição e desenvolvimento de conhecimentos e aptidões, assim como habilidades no processo de saber como fazer música têm muitas similitudes. Neste estudo quase experimental, examinou-se o efeito do ensino da palavra em L1 com música dentro do nível normal de inteligência e desenvolvimento dos alunos de $2^{\circ}$ grado sobre a aprendizagem do significado da palavra e a garantia da permanência da palavra. No estudo se utilizaram como ferramentas de coleta de dados palavras cujos significados provavelmente não sejam conhecidos pelos estudantes, em contextos, e provas de sucesso preparadas para medir o significado destas palavras. A pesquisa foi realizada com 43 estudantes de segundo grau e os dados se analisaram com a prova ANOVA. De acordo com os resultados do estudo se concluiu que se encontrou útil o ensino das palavras com música tanto para a aprendizagem do significado da palavra quanto para sua sustentabilidade. Além disso, quando se examina a permanência ou a constância das operações, se revelou que ensinar vocabulário com música também apoia a aprendizagem permanente.

Palavras Chave: Música, ensino de vocabulário, aprendizagem do significado da palavra, permanência, graus elementares, língua materna 


\section{Introduction}

М hen educational researches conducted in recent years are examined, it is seen that multi-disciplinary studies come to the fore (Gruenewald, 2003). The fact that the teaching activities are specific to a single area is insufficient in academic and general academic success in that area. For this reason, it is more challenging to reach educational goals (Stubbs, Zimmerman, Warner, \& Myers, 2018). At this point, it is essential to configure the areas to be established while teaching correctly. Because these areas will be included in the teaching processes together, a relationship must be established in the student's mind cognitively. It is known that the use of artistic works in language teaching is a correct structure. Music is one of the areas recommended for language teaching (Feld \& Fox, 1994). Music should be an essential factor in language teaching. With music's help, students express themselves more enjoyably, giving more advantage for communicating with others and expressing themselves, and getting relaxed (Linnavalli, Putkinen, Lipsanen, Huotilainen, \& Tervaniemi, 2018). Studies show that continuing together music and language teaching has many positive results (Winters \& Griffin, 2014). Because while students learn something through music, they also enjoy this process. At this point, the fact that the students were entertained in the teaching process increased the success. In addition, since music is an area in which language skills are used, it is considered useful for students' language development (Jahan, 2017).

\section{Literature Review}

Little children are naturally inclined to action, clapping, dancing, and having fun with music. It is stated that this disposition originates from the nature of the child having music and rhythm (Winters \& Griffin, 2014). This means that when a child is singing and tapping out a rhythm, start dancing upon hearing music; it is a product of the child's inner motivation and his/her desire. Thus, it is thought to be useful that this self-motivated activity of the child is combined with language teaching; because language learning shows a dull characteristic, especially for the little aged children. Besides that, language teaching only by the use of a single method is often insufficient. Within this context carrying out music and language teaching would enable both fields to be more permanently acquired and the process to be more fun.

It is known that music and language development have a meaningful relationship. Streeter (1976) suggested that newborn infants have common linguistic reactions even though they were born to different geographical regions. Chomsky stated that infants are born with an innate linguistic capacity in the later years, and their language development follows similar steps even in different communities. After Chomsky, Locke 
asserted that infants have an innate capacity to distinguish sounds, including musical sounds. Many researchers stated that language and music capacities are innate, and they have an inseparable connection (Fedorenke, Patel, Casasanto, Winaver, \& Gibson, 2009; Peretz, 2006). From this point of view, language and music are more meaningful in consideration of the human's biological structure, and it can be concluded that they will support educational studies in this field.

It is more important to maintain these two areas interactively, especially in primary school age. Because many skills for children of primary school age are very open to development. The primary school period is very critical for the development of students' language skills too. Language skills developed in this period will positively reflect students' academic success and social relations in the future. Thus, it is considered important to use music activities that students have fun to improve their language skills in primary school period (Savitri \& Rahman, 2016).

\section{Vocabulary Learning}

One of the most important aspects of language learning is vocabulary learning; it starts with birth and continues until the end. In other words, the person's words throughout his/her life (Celis Nova, Onatra Chavarro, \& Zubieta Córdoba, 2017) affect the whole life. However, a person learns much more words during childhood. While the word learning process before formal education is mostly family and environment-centered, it takes a more systematical form with the introduction of the curriculum at the primary school. This aims to increase the number of words required for the learning process and behavioral change. In addition to this, words are crucial for understanding courses, framing correct communication, and actively using socializing skills. Many researchers agree that vocabulary learning is one of the most important steps of mother tongue acquisition (Fan, 2003; Gu, 2003; Ma 2009).

Teaching words have high importance concerning language acquisition. Because of this, it is recommended to use different methods and techniques while teaching vocabulary. The first and most classic method is using a dictionary. When students encounter an unknown word in classes, they look it up from their dictionaries and see these words in sentences. Then, they use those words in their sentences.

Another method used in teaching vocabulary is using visual prompts. While teaching a word with visual prompts, a visual prompt containing the meaning of the word is shown to the students, and then the meaning is given to them. Thereby, students can visually see the word which they have just learned.

The verbal explanation is also a commonly used technique in teaching vocabulary. In this technique, the teacher explains the meaning of the word verbally; and synonyms, 
antonyms, and homonyms are found with the students' interaction. Context-based vocabulary teaching is a technique for teaching vocabulary. In this technique, words are given within a context, and the meanings are comprehended by the students (Gür, 2014). Apart from these techniques mentioned above, another technique used in teaching vocabulary is teaching vocabulary through music.

\section{Building Bridges between Music and Vocabulary Skills}

It has been found that, since there is a close resemblance between musical and linguistic structures, children singing songs has a fast development in many linguistic skills, especially vocabulary skills (Cohen, 2010; Montgomery, 2002; Piro \& Ortiz, 2009). This situation reveals that teaching vocabulary through music is useful. Montgomery (2002) claimed that music and language are parallel with each other in terms of grammatical structure, phoneme, syntax, and semantics. It is thought that this parallel structure helps accelerate students' language development when their teaching vocabulary is combined with music. Also, it has been proved that singing and music books help improve students' vocabulary learning (Montgomery, 2012).

Besides, music has a profound effect on memory (de Groot, 2006). Researchers have reported that music increases memory power more than many other methods. This effect also exists for vocabulary teaching. Even though this effect is mainly used in L2 learning (de Groot, 2006; Engh, 2013; Zeromskaite, 2014) it can be considered a factor that explains the better understanding of words for vocabulary teaching in the mother tongue. Students who continuously repeat words through music understand the meaning of words and their use in sentences better. This is a good way for them to learn words better. This situation, as a whole, created a curiosity about the effect of combining vocabulary teaching and music on Turkish students' vocabulary learning.

However, it is also known that teaching vocabulary through music has some challenges for the teachers. First of all, in teaching vocabulary through music, writing lyrics and composing them to teach unknown words is a hard task that requires mastery; lyrics should both give the meaning of the word and be in line with students' level. Besides that, lyrics must be composed to be sung with the students, which is a time-consuming task. These challenges may be hard to overcome; however, they can be achieved by cooperating with teachers of different disciplines. For example, a class teacher can cooperate with the music teacher to teach vocabulary through music. In this way, the responsibility can be divided, and the process does not take too long for just one teacher; and this also improves teachers' interdisciplinary skills. 


\section{Justification of the Study}

When the literature concerns the relationship between music and language is carefully examined, there is a belief that it should be useful to carry out these studies together. However, the challenge of carrying out these studies together arises as a restricting factor. Besides, it is stated that studies on music and language acquisition are mostly carried out with individuals who have literacy disadvantages like dyslexia (Welch, Saunders, Hobsbaum, \& Himonides, 2012). Also, few studies on music and vocabulary teaching at the primary school level (Ho, 2017). It is seen that studies on this subject are mostly on second language teaching (Jahan, 2017, Palacios \& Chapetón, 2014). In this context, studies are needed to examine the effects of teaching vocabulary with music on learning the meaning of the word and ensuring its permanence in terms of revealing how it will be handled systematically. Also, the fact that this study has been carried out with have normal intelligence and development level students increases its importance. In this context, in this study, the effect of teaching words with music with the normal intelligence and development level of 2 nd-grade students on the learning of the meaning of the word and ensuring the permanence of the word has been examined.

\section{Method}

\section{Research Design}

In this research, a quasi-experimental design with the experimental and control group was used for collecting, analyzing, and interpret the data. We examined the effect of teaching vocabulary through music with the normal intelligence and development level of 2nd-grade students in Turkey on learning the meaning of the word in mother tongue and ensuring the permanence of the word.

Researchers are to study with predetermined, existing groups rather than artificial ones developed by them in educational studies. The reason for this is it is not possible to create artificial groups within the continuing education process. Researchers use existing ready groups since they cannot randomize students to create artificial groups. In those studies, while the experiment and control groups are randomly determined, these groups' subjects cannot be randomly chosen since it is not possible to create artificial groups during the education process. Especially for the studies carried out with students in formal education, appointing students to experiment and control groups would create setbacks for the education process. Because of this, pedagogues prefer predetermined, not artificial groups and quasi-experimental designs (Creswell, 2012; Fraenkel et al., 2011; Mertens, 2010). The researcher randomly appointed an experiment and a control group among similar groups with similar properties 
according to analysis results. Thereby, it is aimed to minimize threats on internal validity brought to the research field by the nature of the quasi-experimental design.

In this study, at first quantitative data collected, and the effect of teaching words with music on 2nd-grade students' learning the meaning of the word and ensuring the word's permanence has been examined. Unusually, it has been examined whether the independent variable (teaching vocabulary through music) affects the dependent variable (2nd-grade students' learning the meaning of the word and ensuring the permanence of the word). Below, the figure of the quasi-experimental design has been shown.

Table 1. The Figure of Quasi-experimental Design

\begin{tabular}{|c|c|c|c|c|c|}
\hline Determining & Groups & Pre- test & Experimental process & Post-test & Permanence Test \\
\hline M & G1 & O1 & X & O2 & O3 \\
\hline & G2 & O4 & & O5 & O6 \\
\hline
\end{tabular}

Note: M: Matching G1: Experimental Group G2: Control Group X: Teaching vocabulary through music studies O1, O4: Pre-test Scores O2, O4: Post-test Scores O3, O6: Permanence Test Scores

\section{Study Group}

During the 2017-2018 education year spring term, the study was carried out with 43 primary school 2nd-grade students in Bursa province's Nilüfer district in Turkey. Since the quasi-experimental design was used in this study, population and sample were not determined; instead, study groups were determined. Pre-testing was carried out in determining the experimental and control groups, and the two closest groups were determined for the study. The school where the study was carried out was designated on a volunteer basis. Before the study, class teachers of Nilüfer district were consulted and informed that a study on the effect of teaching words with music with the normal intelligence and development level of 2nd-grade students on learning the meaning of the word and ensuring the permanence of the word will be carried out. They were also informed about the study process. After that, a school was designated for the study according to these meetings with the teachers. A meeting with the teachers was also arranged at the designated school. Following the teachers' feedback, two teachers who are voluntary and can carry out teaching vocabulary through music according to determining process procedures in their classes were chosen among them. Required permissions were taken for the study. 


\section{Data Collection Tools}

In the study, words, whose meanings are unlikely to be known by the students, in contexts, and success test prepared to measure these words' meanings were used as data collection tools. The questions of the test were prepared as multiple answer questions, true-false questions, and open-ended questions. In the pre-test, post-test, and permanence test, two same texts were used; and 12 questions - 6 questions for each word- about two words, the same words in each text, in those texts were asked (see appendix 1).

While preparing the success test, qualifications needed to be fulfilled by the students were examined, and in accordance with these expectations, questions prepared to test the knowledge of the word meaning, the awareness of the contextual usage of the word, correctly using the word in a sentence, knowing synonyms, homonyms, and far-linked words, and using the word in association with the daily life situations. When preparing the questions, the dimensions of remembering, understanding, and implementing the meaning of the word are considered. After preparing the questions, two experts in the field of class teaching and one expert in the field of Turkish teaching were asked for their opinions; and the data collection tool was finalized in consideration of their feedback.

Before the beginning of the study, the data collection tool was applied in a class by a volunteered teacher. At the end of this pilot scheme, the data collection tool was concluded to be applicable in the study.

\section{Data Analysis}

Normality tests were completed to identify the pattern of variables. The scores obtained from the students in the groups were analyzed with an ANOVA test. The difference between pre-test/post-test and permanence results of the experimental group and the difference between pre-test/post-test and permanence results of the control group were analyzed with the Bonferroni test. Type 1 error was pegged at $5 \%$ level $(\mathrm{p}<.05)$. For the discrete and continuous variables in the study, supplementary variables included mean, standard deviation, standard error, median, minimum, maximum, number, and percentage.

\section{The Instruction Procedure}

In this study, the texts were read, and the meaning of the selected words was asked to the students. Later, the meaning of these words was explained, and the students were asked to use the words in sentences. After this stage, sentences create about these words were written in their notebooks. The studies so far have been similar in the 
control group. Subsequently, the songs prepared about the words were played to the students in the experimental group, and they were sung many times with them. The songs' meaning was discussed, and an effort was made for the students to memorize the songs. In this process, it was observed that the students also sang outside of the classroom, for example during the breaks and after school. These operations were not performed in the control group.

\section{The Implementation Process}

After the school's designation, where the study would be conducted, texts and words to be used in those texts were determined. Concerning these words, success tests were prepared following the processes mentioned in the data collection tools section. After that, composing songs, which would reflect the meanings of those words, started. During this process, firstly, lyrics were written with the help of an academician in music teaching. It was our priority for the lyrics both to reflect the meaning and show its contextual usage (see appendix 2). After writing the lyrics, music and rhythm were added, and songs were recorded in a professional studio. Then, the songs were shared with the experimental group teacher; and s/he was instructed about how to use them. The teacher was told at which stage of the lesson she would perform these songs.

After this process, pre-tests were first done, and later texts were treated with both the experimental and control groups. While in the control group, the teacher taught the words according to the methods and techniques that should be followed in the Turkish Lesson (Primary and Secondary School 1-8 Grades) Education Program (Ministry of National Education [MoNE], 2015); in the experimental group, the words were taught along with the songs. In this process, a lesson program was prepared for both teachers to reduce the effect caused by the teacher, and they were warned not to go out of the curriculum. Finally, for both groups, post-tests were implemented. After the post-tests, we waited for some time, and after five months, permanence tests were conducted on both groups; and the study was concluded.

To control the external variables that may affect the research's dependent variable, it was tried to ensure that all the activities except the program conducted throughout the application were the same. This issue was discussed with teachers and school administration. Thus, external factors that may affect the research result were minimized.

\section{Findings}

Depending on the research's purpose, statistical analyses were performed on the data obtained from the measurement tools through the SPSS program, and the 
findings obtained are shared below. In this framework, the students' mean scores in the experimental and control groups from the word success test were compared. Descriptive statistics about the vocabulary pre-test and post-test scores of the students in the experimental and control groups are given in Table 2.

Table 2. Descriptive Statistics of the Students in the Experimental and Control Groups word success Pre-test and Post-test Average Scores

\begin{tabular}{|c|c|c|c|c|}
\hline Test & Groups & N & X & Standard deviation \\
\hline \multirow{2}{*}{ Pre-test } & Control & 21 & 30,80 & 7,64 \\
\cline { 2 - 5 } & Experiment & 22 & 29,18 & 5,32 \\
\hline \multirow{2}{*}{ Post-test } & Control & 21 & 33,09 & 4,49 \\
\cline { 2 - 5 } & Experiment & 22 & 38,90 & 5,01 \\
\hline \multirow{2}{*}{ Permanence test } & Control & 21 & 33,04 & 2,85 \\
\cline { 2 - 5 } & Experiment & 22 & 39,22 & 3,16 \\
\hline
\end{tabular}

When Table 2 is examined, is examined, the experimental group students' average scores in the vocabulary teaching activities before the experiment were $=29.18$; this value was $=38.90$ after the instruction process. While the average scores of the control group students before the experiment were $=30.80$, it increased to $=33.09$ after the courses were carried out within the Turkish Lesson Curriculum framework. When the average of permanence test is analyzed, it is seen that the average of the experimental group increased to $=39.22$ and the average of the control group decreased to $=33.04$.

To determine whether the change between the pre-test, post-test, and permanence test mean scores of the experimental and control groups was statistically significant, an ANOVA test was performed for Mixed Measurements. More than one t-test can be done to make these comparisons, but as the number of analyzes performed increases, the error margin of t-tests will increase exponentially. For this reason, the ANOVA test was preferred for Mixed Measurements. The analysis results for this test are given below.

One of the prerequisites that must be met to provide reliable results for the ANOVA test for mixed measurements is that the scores of the dependent variable show the normal distribution in each group (Büyüköztürk, 2012, p. 79). To determine whether the dependent variable scores show the normal distribution in each group, the skewness coefficient (SC) and kurtosis coefficient (KC) of the data were examined. The data on the skewness and kurtosis coefficients of the students' pre-test and posttest scores are given in Table 3. 
Table 3. Descriptive Statistics of the Students' Pre-test and Post-test Average Scores

\begin{tabular}{|c|c|c|c|c|c|c|}
\hline Groups & Tests & $\mathbf{N}$ & $\mathbf{X}$ & Standard deviation & SC & KC \\
\hline \multirow{4}{*}{ Control } & Pre-test & 21 & 30,80 & 1,66 &, 367 &,- 420 \\
\cline { 2 - 7 } & Post-test & 21 & 33,09 &, 98 &,- 171 &,- 577 \\
\cline { 2 - 7 } & Permanence test & 21 & 33,04 &, 62 &,- 067 & $-1,154$ \\
\hline \multirow{3}{*}{ Experiment } & Pre-test & 22 & 29,18 & 1,13 &, 834 &, 117 \\
\cline { 2 - 7 } & Post-test & 22 & 38,90 & 1,06 &,- 617 & $-1,154$ \\
\cline { 2 - 7 } & Permanence test & 22 & 39,68 &, 44 &,- 161 &,- 704 \\
\hline
\end{tabular}

The fact that skewness and kurtosis's coefficient is close to zero indicates that the distribution is approaching normality. When the distribution is normal, skewness and kurtosis values will be zero (Tabachnick \& Fidell, 2014, p. 113; Field, 2018, p. 345). However, George and Mallery (2019, p. 114) stated that the coefficient of skewness and kurtosis between 2 and +2 is acceptable in terms of the normality assumption. When Table 3 is examined, it is seen that the skewness and kurtosis coefficients of both experimental and control groups are distributed between -2 and +2 . Based on these values, it can be said that the data obtained from the experimental and control groups show normal distribution.

Another assumption that the ANOVA test for Mixed Measurements must be met to provide reliable results is that the variances of the groups are homogeneous in each measurement performed more than once (Can, 2013, p. 222). Accordingly, the Levene test was conducted to determine whether there is a significant difference between the variances of the pre-test, post-test, and permanence test measurements of the experimental and control groups. The results for the Levene test are given in Table 4.

Table 4. Levene Test Results on the Homogeneity of Variances of Word Success Pretest, Post-test and Permanence Measurements

\begin{tabular}{|c|c|c|c|c|}
\hline Tests & F & sd1 & sd2 & p \\
\hline Pre-test & 3,719 & 1 & 41 &, 061 \\
\hline Post-test &, 337 & 1 & 41 &, 565 \\
\hline Permanence test & 2,496 & 1 & 41 &, 122 \\
\hline
\end{tabular}

When the Levene test results given in Table 4 are examined, it is seen that there is no difference between the variances of the pre-test, post-test, and permanence test measurements of the experimental and control groups

$$
\left[\mathrm{F}_{\text {pre-test }}(1-41)=3.719 ; \mathrm{F}_{\text {post-test }}(1-41)=0.337 ; \mathrm{Fp}_{\text {ermanence }}(1-41)=2.496 ; p>.05\right]
$$


The ANOVA test's final requirement for Mixed Measurements to provide reliable results is the assumption of sphericity and no significant difference between the covariances of the groups for binary combinations of measurement groups. The situation was checked with the Mauchly Sphericity Test and Box's Test of Equality of Covariance Matrices test. The results for Mauchly Sphericity Test are given in Table 5, and the Box's Test of Equality of Covariance Matrices test are shown in Table 6.

Table 5. Word Success Pre-test, Post-test and Permanence Measurements Sphericity Test Results

\begin{tabular}{|c|c|c|c|c|c|c|}
\hline Measurement & Mauchly W & $\mathbf{x}^{2}$ & $\mathbf{s d}$ & $\mathbf{p}$ & $\begin{array}{c}\text { Greenhouse- } \\
\text { Geisser Correction }\end{array}$ & $\begin{array}{c}\text { Huynh-Feldt } \\
\text { Correction }\end{array}$ \\
\hline $\begin{array}{c}\text { Word Success } \\
\text { Test }\end{array}$ &, 598 & 20,556 & 2 &, 000 &, 713 &, 750 \\
\hline
\end{tabular}

According to the Mauchly Sphericity Test Results given in Table 5, when the values obtained for the repeated measurements taken from the Word Success Test are examined, it is seen that the sphericity assumption cannot be achieved $\left(\mathrm{W}_{(2)}=.598, p<\right.$ $.05)$. For this reason, while analyzing the group's effect regarding the scores obtained from this test, Greenhouse-Geisser correction was made, and the values calculated by SPSS were used.

Table 6. Box's M Test Results Regarding Equality of Covariance Matrix

\begin{tabular}{|c|c|}
\hline Box's $\mathbf{M}$ & $\mathbf{9 , 9 2 3}$ \\
\hline $\mathrm{F}$ & 1,522 \\
\hline $\mathrm{df1}$ & 6 \\
\hline $\mathrm{df} 2$ & 12102,089 \\
\hline $\mathrm{p}$ &, 166 \\
\hline
\end{tabular}

According to the analysis results in Table 6, it can be said that there is no significant difference between the covariances of the experimental and control groups

$\left[\mathrm{F}_{(6-12102,089)}=9.923 ; p>.05\right]$

All these findings show that all of the prerequisites required to provide reliable results for the ANOVA test for Mixed Measurements are met. Accordingly, ANOVA analysis was conducted for Mixed Measurements regarding whether the difference between the mean and pre-test, post-test, and permanence test mean scores of the experimental and control groups were statistically significant. The results are presented in Table 7. 
Table 7. ANOVA Results Regarding the Vocabulary Success Pre-test, Post-test and Permanence Test Scores of the Students in the Experimental and Control Groups

\begin{tabular}{|c|c|c|c|c|c|}
\hline Source of Variance & $\begin{array}{c}\text { Sum of } \\
\text { Squares }\end{array}$ & df & $\begin{array}{c}\text { Mean } \\
\text { Square }\end{array}$ & F & $\mathbf{p}$ \\
\hline Between-Subjects & 1713,581 & 42 & & & \\
\hline Group (Individual/Group) & 419,309 & 1 & 419,309 & 13,283 &, 001 \\
\hline Error & 1294,272 & 41 & 31,568 & & \\
\hline Within-Subjects & 1551,569 & 61,3749 & & & \\
\hline Measure & 1099,835 & 1,427 & 770,895 & 27,237 &, 000 \\
\hline (Pre-test/Post-test/Permanence test) & 445,199 & 1,427 & 312,049 & 11,025 &, 000 \\
\hline Group ${ }^{\star}$ Measure & 1655,592 & 58,495 & 28,303 & & \\
\hline Error & 3265,15 & 103,349 & & & \\
\hline
\end{tabular}

The results of the ANOVA analysis in Table 7 show that the group effect of the students in the experimental and control groups on the mean scores of the word success pre-test, post-test and permanence test is significant $\left[\mathrm{F}_{(1-41)}=13.283 ; p<.05\right]$. Based on this finding, it can be said that there is a significant difference between the averages of the experimental and control groups' word success test without making a distinction in the form of pre-test, post-test, and permanence test measurements.

As a result of the ANOVA analysis, it was found that the difference between the mean scores obtained from the pre-test, post-test, and permanence test measurements conduct in the study within the scope of the research was statistically significant $\left[\mathrm{F}_{(1,427-}\right.$ $\left.{ }_{58,495)}=27.237 ; \mathrm{p}<.05\right]$. This finding shows that when no group distinction is made, the students' word success varies depending on the experimental process. Also, as a result of the examination of the common effect (group * measurement effect) that is important for the research within the scope of this analysis, the vocabulary success of all students participating in the semi-experimental research differed statistically significantly from before the experimental process to the post-experimental process, that is, the factors of repetitive measurements were read by being different process groups. Common effects on comprehension success were found to be significant $\left[\mathrm{F}_{(1,427-58,495)}=11.025 ; p<\right.$ .05]. According to these findings obtained from ANOVA analysis, the Bonferroni test, which is one of the post-hoc binary comparison tests, was carried out to determine between which groups the difference was significant depending on the measurements between the groups. The Bonferroni test is a type of multiple comparison test used in statistical analysis. This test should be used when performing multiple comparative hypothesis tests. The results for the Bonferroni test are given in Table 8.

Table 8. Bonferroni Test Results Regarding Vocabulary Success Pre-test, Post-test, and Retention Test Scores of the Experimental and Control Groups 


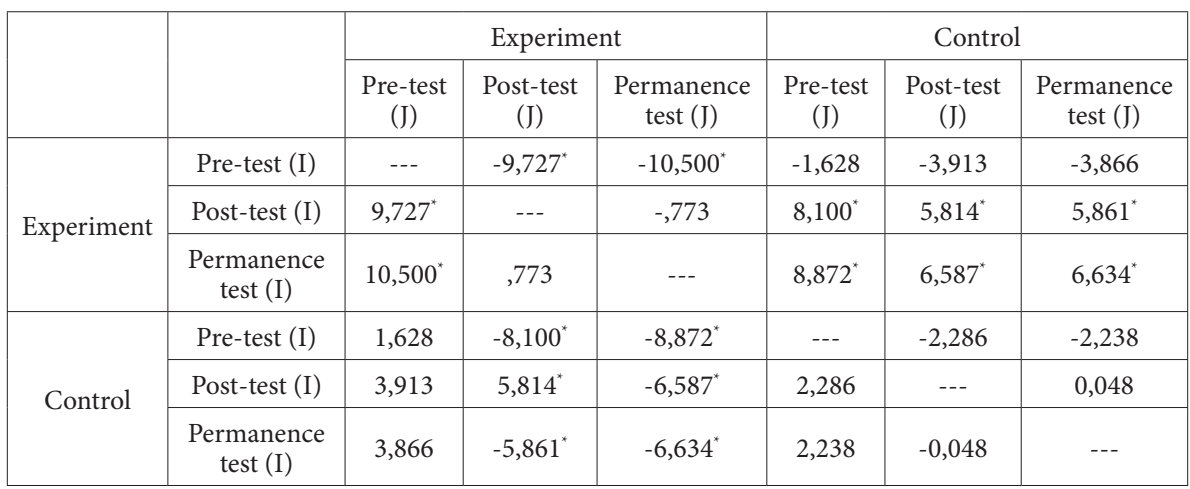

When the Bonferroni comparison results in Table 8 are analyzed, it is seen that there is no significant difference between the pre-test mean scores of the experiment $(=29.18)$ and control group $(=30.80)$ students. Based on this result, it can be said that the groups included in the research are equal in terms of word success before the experimental study. After performing the experimental procedures, it is understood that the difference between the experimental $(=38.90)$ and the control group $(=33.09)$ post-test mean scores is statistically significant. The same is true for the permanence test results. When the results were examined, it was found that there was a significant difference between the mean scores of the permanence test of the experiment $(=39.68)$ and control group $(=33.04)$ students. The findings obtained as a result of the analysis are also shown in the graph of change. The change graph for the ANOVA test for Mixed Measurements is given in Figure 1.

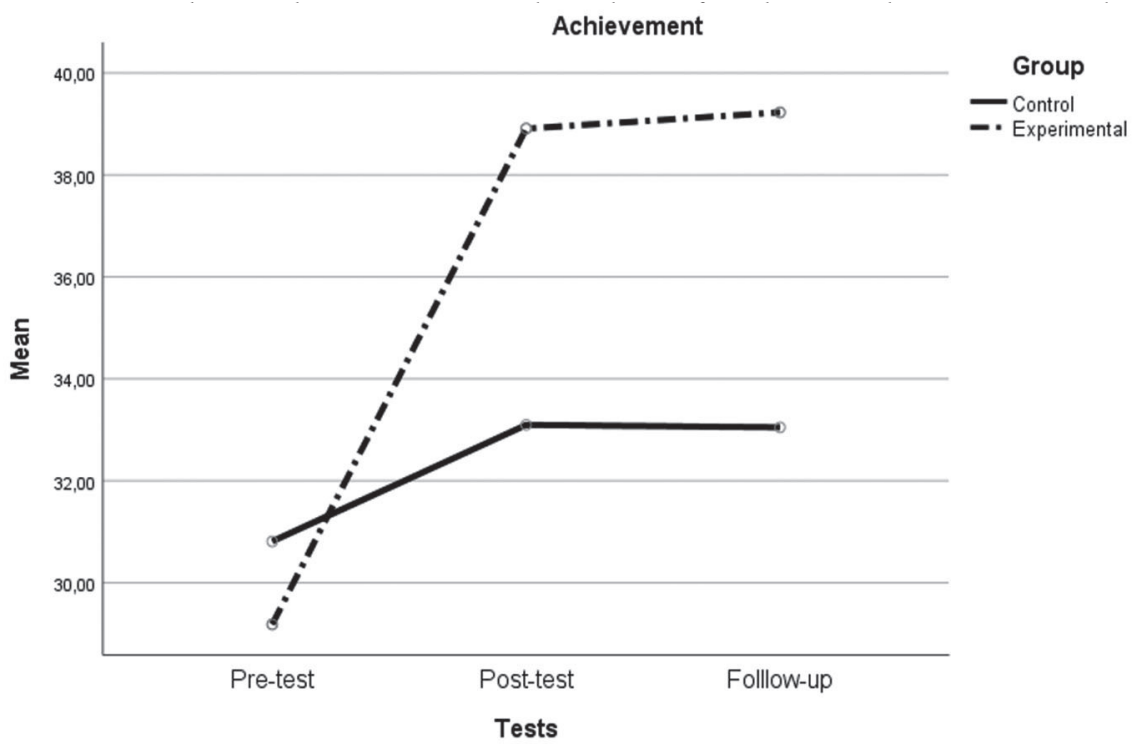


When Figure 1 is analyzed, it can be seen that the mean scores of students in the experimental and control groups increased in the semi-experimental application process. After 120 days of semi-experimental practice, the students' word success score increased in the experimental group, but the control group's average score decreased.

\section{Conclusion, Discussion, and Suggestions}

Since it is stated that studies literature on music and language acquisition is mostly carried out with individuals who have literacy disadvantage (like dyslexia); in this study, the effect of teaching words with music has the normal intelligence and development level students that is, does not need special education on the learning of the meaning of the word and ensuring the permanence of the word has been examined. According to the study results, it is concluded that the teaching of vocabulary with music, both the meaning of the word and providing the permanence of learning, was found to be useful.

Tripney (2010), with the meta-analysis study that he carried out, emphasized the link between music and learning; and investigated how teaching music affects other fields of learning. Within this research scope, twenty-four studies have been examined; and music-related teaching has been seen to be useful for audio awareness, vocabulary knowledge, and word fluency. Dockrell, Stuart, and King (2000) made audio-book reading sessions with the program they prepared for the students. At the end of the study, they concluded that it had a meaningful difference in vocabulary knowledge and understanding what they read. In their study with 46 students between the ages of six and nine, Corrigal and Trainor (2011) stated a relationship between understanding what the students read and the length of their music education. And, also, Gromko (2005), Register et al. (2007), and Piro and Ortis (2009) stated that music education affects understanding what one reads. Stanley and Hughes (1997) also revealed that music impacts students' writing skills.

When all these studies are considered, it can be concluded that music can be useful for skills related to different dimensions of native language education. It is noticeable that some reasons for the improvement are stressed when we analyze the results of studies on the effect of music on language learning.

First of all, teaching with music has many advantages; and the improvement seen on the students can be transferred to other fields and helps students' language skills be improved one of the most remarked advantages. Devlin and Seidel (2009) stated that the music education systematically given to the students might help students to develop many skills that they can use at many different levels throughout their lives. These skills include creativity, connections between different situations, esthetical awareness, and self-expressiveness (McIntre, 2007). 
One of the reasons why teaching music helps improving language skills, especially vocabulary learning, is that the vocalization of symbols while reading resembles the process of vocalization in music. For example, the process of reading notes and vocalizing them while playing a musical instrument or singing resembles following and understanding symbols while reading (Hamsen \& Bernstore. 2002). Similarly, both reading notes in music and vocalizing letters while the normal reading process goes from left to right. This factor is thought to be the leading, supporting factor why music is useful for many skills like vocabulary learning and reading (Lloyd, 1978).

Morrow (1996) defended the idea that music can be very useful for vocabulary teaching. Morrow especially stressed the affective aspects of music on children and claimed that enjoyable songs might help students learn the meaning of words. Woodall and Ziembroski (2004) stressed that words learned while listening to songs could be a resourceful vocabulary learning unit. When this study is evaluated and other studies in the literature, it can be concluded that music is useful in developing a lot of skills besides understanding what has been read and vocabulary learning. However, as we mentioned in the introduction, the scarcity of studies conducted with normal students is highly remarkable. So, studies conducted with students of normal intelligence and development levels on the effects of music on language skills are needed more. Besides, in this study, the effect of music on learning the meaning of the word and ensuring the permanence of the word has been examined. Yet, it is suggested for other studies to be conducted on the possible effects of teaching words with music with the normal intelligence and development level of students on the learning of the meaning of the word and ensuring the permanence of the word to be examined. Besides, the studies are recommended to be emphasizing students' affective aspects and what they experienced during the process. In this respect, it is thought to be important that, after the students are taught music, the qualitative analysis should be done about what they experienced and how they felt. According to the studies conducted, it is thought to be useful to combine music with other teaching fields instead of being a separate lesson. Within this context, it shouldn't be forgotten that academicians, politicians, and pedagogues, who arrange education programs, have a big responsibility to integrate music and art activities with other classes.

\section{Limitations of the Study}

It is also known that teaching vocabulary with music has difficulties for teachers. First of all, writing and composing lyrics for words with unknown meaning in word teaching with music is a difficult task that requires expertise. Because it requires both written lyrics to give the meaning of the word, and these words should be prepared according to students' age levels. Apart from this, it takes time to compose the written song and make it readable with students. Even such compelling reasons can make this technique difficult to use, but it can be achieved through cooperation and teachers' 
help working in different disciplines. For example, a classroom teacher can practice the word teaching technique with music and the school's music teacher. In this way, both the tasks are shared, and the responsibility is shared among the teachers, and the process is not too long for a teacher, and the teachers' interdisciplinary working skills develop. Apart from this, the sample size is small for this research, which is considered a limitation. For this reason, it is recommended to work with a larger sample size in future studies. 


\section{References}

Büyüköztürk, Ş. (2011). Handbook of data analysis for social sciences: Statistics, research design spss applications and interpretation [Sosyal Bilimler için Veri Analizi El Kitabı İstatistik, Araştırma Deseni SPSS Uygulamaları ve Yorum]. Ankara: Pegem Akademi.

Celis Nova, J., Onatra Chavarro, C. I., \& Zubieta Córdoba, A. T. (2017). Educational videos: a didactic tool for strengthening English vocabulary through the development of affective learning in kids. GIST - Education and Learning Research Journal, (14), 68-87. https://doi.org/10.26817/16925777.368

Cohen, A. (2010). Advanced interdisciplinary research in singing: Development, education, and well-being: Milestone document (April 1, 2009-September 30, 2012). Retrieved from: http://www.airsplace.ca/node/453

Corrigall, K. A., \& Trainor, L. J. (2011). Associations between length of music training and reading skills in children. Music Perception: An Interdisciplinary Journal, 29(2), 147-155. https://doi.org/10.1525/mp.2011.29.2.147

Creswell, J. W. (2012). Qualitative inquiry and research design: Choosing among five approaches. California: Sage Publications.

de Groot, A. M. (2006). Effects of stimulus characteristics and background music on foreign language vocabulary learning and forgetting. Language learning, 56(3), 463-506.

Devlin, J. M., \& Seidel, S. (2009). Music preferences and their relationship to behaviors, beliefs, and attitudes toward aggression. Retrieved from: https://files.eric.ed.gov/ fulltext/ED507397.pdf

Dockrell, J. E., Stuart, M., \& King, D. (2010). Supporting early oral language skills for English language learners in inner city preschool provision. British Journal of EducationalPsychology,80(4),497-515.https://doi.org/10.1348/000709910X493080

Engh, D. (2013). Why use music in English language learning? A survey of the literature. English Language Teaching, 6(2), 113-127.

Fan, M.Y. (2003). Frequency of use, perceived usefulness, and actual usefulness of second Language vocabulary strategies: A study of Hong Kong learners. The Modern Language Journal, 87(2), 222-241. Retrieved from: http://www.jstor.org/ stable/1193034 
Fedorenko, E., Patel, A., Casasanto, D., Winawer, J., \& Gibson, E. (2009). Structural integration in language and music: Evidence for a shared system. Memory \& Cognition, 37(1), 1-9. https://doi.org/10.3758/MC.37.1.1

Feld, S., \& Fox, A. A. (1994). Music and language. Annual Review of Anthropology, 23(1), 25-53. Retrieved from: https://www.jstor.org/stable/2156005

Fraenkel, J., Wallen, N., \& Hyun, H. (2011). How to design and evaluate research in education. New York: Mc Graw Hill.

$\mathrm{Gu}, \mathrm{Y}$. (2005). Vocabulary learning strategies in the Chinese EFL context. Singapore: Marshall Cavendish.

Gromko, J. E. (2005). The effect of music instruction on phonemic awareness in beginning readers. Journal of Research in Music Education, 53(3), 199-209. https:// doi.org/10.1177/002242940505300302

Gruenewald, D. A. (2003). Foundations of place: A multidisciplinary framework for place-conscious education. American Educational Research Journal, 40(3), 619654. https://doi.org/10.3102/00028312040003619

Gür, T. (2014). Using Context based word teaching technique to third grade students [Bağlam temelli öğretimin ilkokul üçüncü sınıf öğrencilerine kelime öğretiminde kullanilmas1]. The International Journal of Turkish Education Sciences, 2(2), 242253. Retrieved from https://dergipark.org.tr/tr/pub/goputeb/issue/7322/95822

Jahan, T. S. (2017). Using music: An effective medium of teaching vocabulary in esl classroom. International Journal of English Language Teaching, 5, 13-23.

Hansen, D., \& Bernstore, E. (2002). Linking music learning to reading instruction. Music Educators Journal, 88(5), 17-52. https://doi.org/10.2307/3399821

Ho, P. S. (2017). Vocabulary learning using music and digital devices: Classroom research at an international school. The 2016 PanSIG Journal, 111-116. Retrieved from: https://pansig.org/publications/2016/2016_PanSIG_Journal.pdf

Linnavalli, T., Putkinen, V., Lipsanen, J., Huotilainen, M., \& Tervaniemi, M. (2018). Music playschool enhances children's linguistic skills. Scientific Reports, 8(1), 1-10. https://doi.org/10.1038/s41598-018-27126-5

Ma, Q. (2009). Second language vocabulary acquisition. Bern: Peter Lang.

McIntire, J. M. (2007). Developing literacy through music. Teaching Music, 15(1), 4449. 
Mertens, D. M. (2010). Transformative mixed methods research. Qualitative Inquiry, 16(6), 469-474. https://doi.org/10.1177/1077800410364612

Ministry of National Education (MoNE). (2015). The elementary school Turkish language arts course (1-8 grades) teaching program and guidance. Ankara: Government Books Press.

Montgomery, A. P. (2002). Teaching towards musical understanding: A handbook for the elementary grades. Toronto: Pearson Education.

Montgomery, A. (2012). Bridging the advocacy gap with song-based picture books. Canadian Music Educator, 54(2), 41-44.

Morrow, L. M. (1996). Literacy development in the early years: Helping children read and write. Needham Heights: Allyn \& Bacon.

Palacios, N., \& Chapetón, C. M. (2014). Students' responses to the use of songs in the efl classroom at a public school in Bogotá: A critical approach. GIST - Education and Learning Research Journal, (9), 9-30. https://doi.org/10.26817/16925777.141

Peretz, I. (2006). The nature of music from a biological perspective. Cognition, 100(1), 1-32. https://doi.org/10.1016/j.cognition.2005.11.004

Piro, J. M., \& Ortiz, C. (2009). The effect of piano lessons on the vocabulary and verbal sequencing skills of primary grade students. Psychology of Music, 37(3), 325-347. https://doi.org/10.1177/0305735608097248

Register, D., Darrow, A. A., Swedberg, O., \& Standley, J. (2007). The use of music to enhance reading skills of second grade students and students with reading disabilities. Journal of Music Therapy, 44(1), 23-37. https://doi.org/10.1093/ jmt/44.1.23

Streeter, L. (1976). Language perception of two-month-old infants shows effects of both innate mechanisms and experience. Nature, 259(5538), 39-41. https://doi. org/10.1038/259039a0

Savitri, D. E., \& Rahman, I. F. (2016). The use of rap music to improve students'vocabulary mastery at the first grade students of Smpn 2 Papalang Mamuju Regency. English, Teaching, Learning, and Research Journal, 2(2), 269-285. https://doi.org/10.24252/ Eternal.V22.2016.A11

Standley, J. M., \& Hughes, J. E. (1997). Evaluation of an early intervention music curriculum for enhancing prereading/writing skills. Music Therapy Perspectives, 15(2), 79-86. https://doi.org/10.1093/mtp/15.2.79 
Stubbs, E. A., Zimmerman, A. R., Warner, L. A., \& Myers, B. E. (2018). Reflecting on a multidisciplinary collaboration to design a general education climate change course. Journal of Environmental Studies and Sciences, 8(1), 32-38. https://doi. org/10.1007/s13412-017-0451-8

Tripney, JS; (2010) The impact of participation in structured arts activities on young people's learning outcomes. Presented at: Culture and Sport Evidence Programme, Royal Opera House/Royal Shakespeare Company/Creativity, Culture and Education, London.

Welch, G., Saunders, J., Hobsbaum, A., Himonides, E. (2012) Literacy through music: A research evaluation of the New London Orchestra's literacy through music programme. London: International Music Education Research Centre. https://doi. org/10.13140/2.1.2629.3447

Winters, K. L., \& Griffin, S. (2014). Singing is a celebration of language: Using music to enhance young children's vocabularies. Language and Literacy, 16(3), 78-91. https://doi.org/10.20360/G2ZK5X

Woodall, L., \& Ziembroski, B. (2004). Promoting literacy through music. Retrieved from: https://www.songsforteaching.com/lb/literacymusic.htm

Zeromskaite, I. (2014). The potential role of music in second language learning: A review article. Journal of European Psychology Students, 5(3), 78-88. 


\section{Authors}

*Ömer Faruk Tavşanlı is an assistant professor in the Faculty of Education at Istanbul Aydin University in Turkey. He completed his PhD in Elementary Education at Bursa Uludag University in Turkey. His research interests include literacy, primary reading and writing, and Turkish language education.

ORCID: https://orcid.org/0000-0003-1366-1679

Abdullah Kaldırım is Dr. in the Faculty of Education at Kutahya Dumlupinar University in Turkey. He completed her PhD in department of Turkish Education at Gazi University in Turkey. His research interests include literacy, Turkish language education, and statistics in education.

ORCID: https://orcid.org/0000-0003-0582-4159

Tayyar Erdem Gedikli is an instructor in the Faculty of Education at Bursa Uludağ University in Turkey. His research interests include music education, children songs and teacher training. He composed hundreds of children songs.

ORCID: https://orcid.org/0000-0002-9582-5384

How to reference this article: Tavsanli, O. F., Kaldirim, A., \& Gedikli, T. E. (2021). Enhancing Permanence on Vocabulary Learning in 2nd Grade Students' Through Music. GIST - Education and Learning Research Journal, 22(1), 51-73. https://doi.org/10.26817/16925777.843 